\title{
Distal radyoulnar eklem biyomekaniği
}

\author{
Biomechanics of the distal radioulnar joint
}

\author{
Egemen Ayhan ${ }^{1}$, Can Emre Baş ${ }^{1}$, Kadir Çevik ${ }^{2}$ \\ 'Sağıı Bilimleri Üniversitesi, Dışkapı Yıldırım Beyazıt Eğitim ve Araştırma Hastanesi, \\ Ortopedi ve Travmatoloji Kliniği, El Cerrahisi Bölümü, Ankara \\ ${ }^{2}$ Mersin Üniversitesi Tıp Fakültesi Hastanesi, Ortopedi ve Travmatoloji Ana Bilim Dalı, El Cerrahisi Bilim Dalı, Mersin
}

\begin{abstract}
Distal radyoulnar eklem (DRUE), proksimal radyoulnar eklem ile senkronize hareket eden, bikondiler ön kol ekleminin bir bileşeni olarak düşünülmelidir. Radiustaki sigmoid çentik ile ulna başındaki konveks eklem yüzeyinin oluşturduğu DRUE'de radius, dönme ve kayma hareketleri ile ulna etrafinda dolanarak pronasyon ve supinasyon hareketlerini yapar. Bu hareketlerle, elin uzaydaki pozisyonu ayarlanır ve kavrama ve benzeri fonksiyonların en az enerji harcanarak yapılabilmesi mümkün olur. DRUE stabilitesi, yüklenmelerin el bileğinden ön kol boyunca dirseğe ağrısız ve uygun transferini, pronasyon ve supinasyon hareketlerinin etkinliğini sağlar. Stabilitede; kemiksel uyum, bağların bütünlügüu, kasların dinamik kompresyonu, interosseöz membran, eklem kapsülü ve propriyosepsiyon etkilidir. Kemiksel uyum ve bağların bütünlüğü stabilitede birincil öneme sahiptir. DRUE yüzeyleri birebir uyumlu değildir, hareket esnasında radiusun bir miktar kayma yapmasına izin verir. Bu durum, pronasyonun ve supinasyonun ileri derecelerinde belirginleşir ve stabilite yumuşak dokular ile sağlanır. DRUE'nin statik stabilitesinden sorumlu en önemli yumuşak doku yapıları, triangular fibrokartilaj kompleks (TFKK) bileşenlerinden olan dorsal ve volar radyoulnar bağlardır. Diğer TFKK bileşenlerinden ulnolunat bağın DRUE stabilitesinde önemli olduğu, ulnotrikuetral bağın ise eklem diski ve menisküs homoloğu ile birlikte ekleme olan aksiyel yüklenmelerde şok absorpsiyonu görevi yaptığı düşünülmektedir. Pronator kuadratus kası DRUE'ye kompresyon uygulayarak, ekstansör karpi ulnaris kası da ulna başının deplasmanına engel olarak dinamik stabilizatörler olarak görev yaparlar. Radyoulnar bağlarda bulunan çok sayıda mekanoreseptörün DRUE stabilitesinde önemli bir propriyoseptif fonksiyonu olduğu düşünülmektedir. DRUE'nin hareketli ve stabil olması, kemik ve bağlar gibi statik bileşenlerin bütünlüğüne ve uyumuna ek olarak, nöromusküler yapıların dinamik etkinliğine bağlıdır. Bu nedenle, DRUE hareketini ve stabilitesini sağlayan yapılar korunmalı ve yaralandığında anatomik olarak restore edilmeye çalışılmalıdır.
\end{abstract}

Anahtar sözcükler: distal radyoulnar eklem; biyomekanik; stabilite, triangular fibrokartilaj kompleksi; radyoulnar bağ
Distal radioulnar joint (DRUJ) moves synchronously with proximal radioulnar joint and should be considered as a part of bicondylar forearm joint. DRUJ is formed by sigmoid notch of radius and convex articular surface of ulnar head. Radius swings around immobile ulnar head during pronation and supination, which comprises rotation and translation of distal radius. Position of hand at space can be adjusted with these motions and grabbing of an object can be achieved with minimum energy consume. Stability provides pain-free transfer of loads from the wrist to the elbow, and allows harmonious pronation and supination. Bone congruency, integrity of ligaments, dynamic compression of muscles, interosseous membrane, joint capsule, and proprioception are elements of stability. Bone congruency and integrity of ligaments are the primary elements. Joint surfaces are not perfectly congruent and allows some translational motion of the distal radius. Translation of the distal radius becomes more evident with the extremes of pronation and supination, thus, further stability is provided with soft tissues. The primary soft tissue structures responsible for static stability are the dorsal and volar radioulnar ligaments of triangular fibrocartilage complex (TFCC). Additionally, the ulnolunate ligament of TFCC is important for DRUJ stability, however, ulnotriquetral ligament along with joint disc and meniscus homologue are important for shock absorption. Pronator quadratus and extensor carpi ulnaris muscles compress DRUJ and act as dynamic stabilizers. Mechanoreceptors, which are abundant in radioulnar ligaments, are considered to have important proprioceptive function for stability. Mobility and stability of DRUJ are dependent on integrity and harmony of static components and dynamic actions of neuromuscular structures. Therefore, structures that provide DRUJ mobility and stability must be preserved and anatomically restored when injured.

Keywords: distal radioulnar joint; biomechanics; stability; triangular fibrocartilage complex; radioulnar ligament

- Illetişim adresi: Doç. Dr. Egemen Ayhan, Dışkapı Yıldırım Beyazıt Eğitim ve Araştırma Hastanesi, Ziraat Mahallesi, Şht. Ömer Halisdemir Blv No:1, 06110 Altındağ, Ankara Tel: 0532 - 6363693 e-posta: egemenay@yahoo.com

- Geliș tarihi: 1 Mayıs $2021 \quad$ Kabul tarihi: 7 Mayıs 2021

ORCID iD: Egemen Ayhan, 0000-0002-0324-3126 • Can Emre Baş, 0000-0003-2734-1756 • Kadir Çevik, 0000-0003-1606-6728 
istal radyoulnar eklem (DRUE), diğer tüm sinovyal eklemlerimiz gibi hareketli ve stabil olmalıdır. DRUE hareketi elin uzaydaki pozisyonunu ayarlar, bu şekilde kavrama ve benzeri el fonksiyonlarını en az enerji harcayarak yapabilmemizi sağlar. ${ }^{[1]}$ DRUE stabilitesi ise yüklenmelerin el bileğinden ön kol boyunca dirseğe ağrısız ve uygun transferini, günlük hayatta çok sık kullandığımız pronasyon ve supinasyon (pro-supinasyon) hareketlerinin etkinliğini sağlar. DRUE'nin yük taşıma esnasında radiusa destek olma işlevi de vardır. Tüm bu işlevler ilgili anatomik yapıların uyumuna, birbirleri içindeki statik ve dinamik ilişkilere bağlıdır. Bu temel bilgilerin iyi anlaşılması, klinikte karşımıza çıkan DRUE sorunlarının nedenlerini ortaya koymak ve tedaviyi belirlemek açısından çok önemlidir.

\section{KINEMATIK}

Distal radyoulnar eklem, proksimal radyoulnar eklem (PRUE) ile senkronize hareket eder ve birlikte ön kol eklemini oluştururlar. ${ }^{[2]}$ Ön kol bu iki kondiler eklem (PRUE ve DRUE) aracilı̆ıyla, proksimalde radius başı merkezinden, distalde ise ulna başı foveasından geçen uzunlamasına eksen üzerinde pro-supinasyon hareketlerini yapmaktadır (Şekil 1). ${ }^{[3]}$ Pro-supinasyon esnasında ulna sabit kalırken radius hareket etmektedir. ${ }^{[1]}$ PRUE'de dairesel radius başı kendi etrafında dönerken, DRUE'de radius distalindeki konkav sigmoid çıkıntı konveks ulna başının çevresinden dolaşmakta, bir tür salınım hareketi yapmaktadır. Bu salınım hareketinde rotasyon (dönme) ve translasyon (kayma) birlikte olmaktadır..$^{[2]}$ Ön kolun toplam pro-supinasyon açısı $150^{\circ}-180^{\circ}$ 'dir. $^{[3]}$

Radius ve ulnanın el bileği eklemindeki birbirleri ile uzunluk uyumuna ulnar varyans denir ve nötral ulnar varyansta radiusun lunat fossasından çizilen yatay çizgi ile ulna distal eklem hattından çizilen yatay çizgi birbirleriyle çakışır. Ulnadan çizilen çizginin radiustan çizilen çizgiden distalde olmasına pozitif ulnar varyans, proksimalde olmasına ise negatif ulnar varyans denir (Şekil 2). Çizgiler arasındaki dikey mesafe ölçülerek ulnar varyansın sayısal değeri saptanabilir. Bu ölçümün radyografik olarak yapılabilmesi için mutlaka el bileği nötral rotasyonda olan standart (gerçek) arka-ön el bilek röntgeni çekilmelidir. Bunun için omuz $90^{\circ}$ abduksiyonda, dirsek $90^{\circ}$ fleksiyonda ve el röntgenin çekileceği masada düz duracak şekilde hastaya pozisyon verilmelidir. Şekil 3'te, standart (gerçek) arka-ön pozisyonda çekilen el bilek röntgeni görülmektedir. Radius, pronasyon ile volar ve proksimal yönde kayma hareketi yapar, bu nedenle pronasyonda çekilecek röntgende hatalı olarak pozitif ulnar varyans gözlenir. Radius, supinasyonda ise dorsal ve distal yönde kayma hareketi yapar, bu nedenle supinasyonda çekilecek röntgende hatalı olarak negatif ulnar varyans gözlenir. ${ }^{[3]}$

Üst ekstremitenin çalışma pozisyonunda genellikle dirsekler fleksiyonda ve el bileği nötral rotasyonda konumlanır. ${ }^{[3,4]} \mathrm{El}$ bileği nötral rotasyondayken triangular fibrokartilaj kompleksin (TFKK) bağ bileşenleri en az gerginliktedir ve radius, ulnanın eklem yüzü üzerinde stabil olarak durur. ${ }^{[5,6]}$ DRUE'ye olan yüklenmeler, eldeki yükün ağırlığına, kasların kasılma kuvvetlerine ve yerçekimine bağlı olarak önemli miktarda olabilmektedir. ${ }^{[3]}$ Yük taşıma esnasında DRUE'ye olan yüklenme (eklem reaksiyon kuvveti), dirsekten etkiyen kas kuvvetinin ve el bileğindeki yükün momentlerinin toplamıdır (Şekil 4). Bu nedenle, ulna eklem yüzündeki kıkırdağın ve sigmoid çentikteki kıkırdak yapının sağlıklı olması kritiktir. ${ }^{[3]}$

El bileğine olan aksiyel yüklenmelerin \%82'si radius tarafından, \%18'i ise ulna tarafından karşılanır. ${ }^{[4]}$ Fakat, pronasyon ve supinasyon pozisyonlarında, radiusun sırasıyla proksimale ve distale bir miktar kayması nedeniyle bu yüklenmelerin oranları değişmektedir. Proksimale, dirsek eklemine yaklaştıkça, ön koldaki interosseöz membranın aracılığıla yüklenmeler radius ve ulna arasında paylaşılır. Ön kola aksiyel yüklenmeler ulnar varyanstan etkilenmektedir. Ulnar $2,5 \mathrm{~mm}$ pozitif varyans durumunda ulnokarpal eklemdeki yüklenme \%42'ye çıkarken, ulnar 2,5 mm negatif varyans durumunda bu yük \%4'e inmektedir. ${ }^{[4]}$

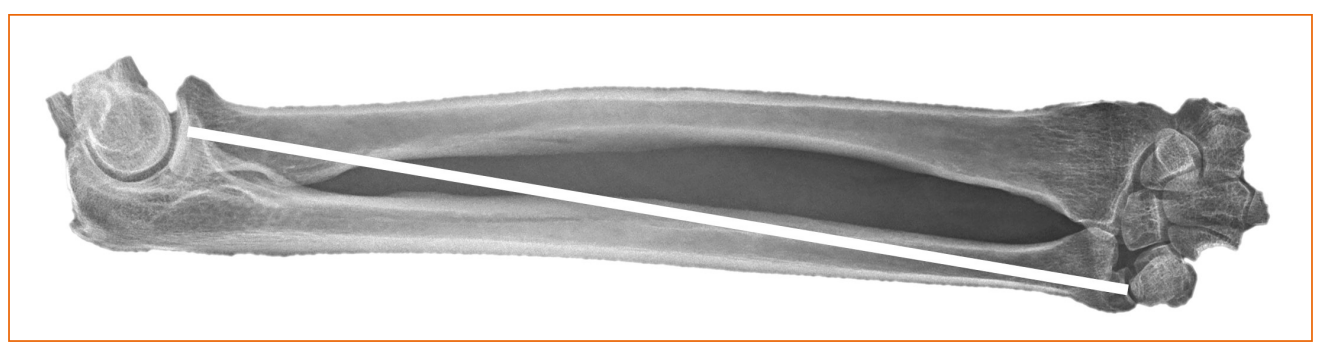

Şekil 1. Ön kol rotasyon (pronasyon ve supinasyon) ekseni. 

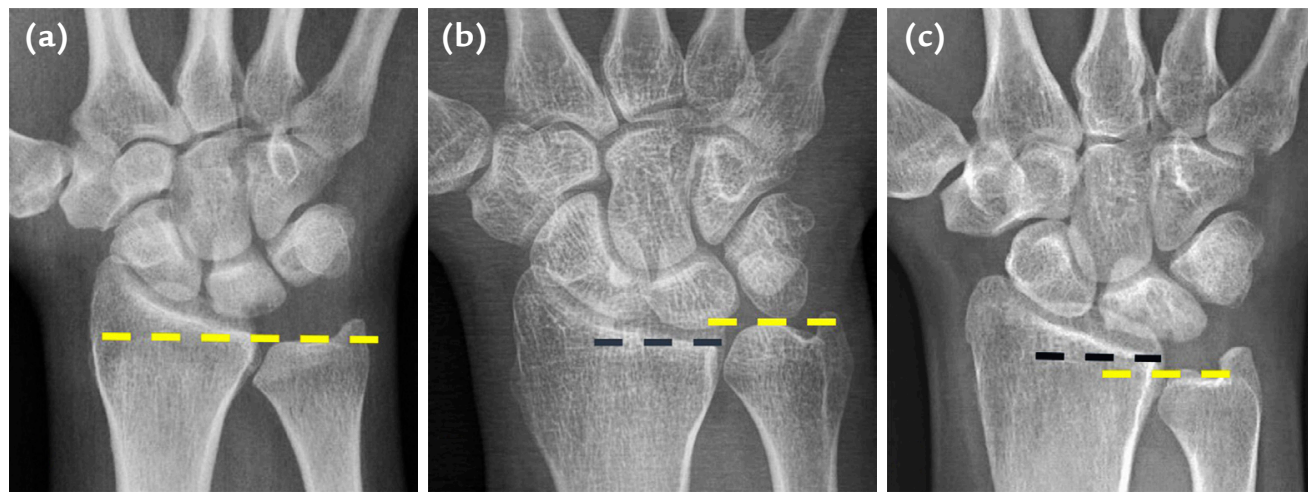

Şekil 2. a-c. Ulnar varyansın belirlenmesi: nötral ulnar varyans (a), Pozitif ulnar varyans (b), Negatif ulnar varyans (c).

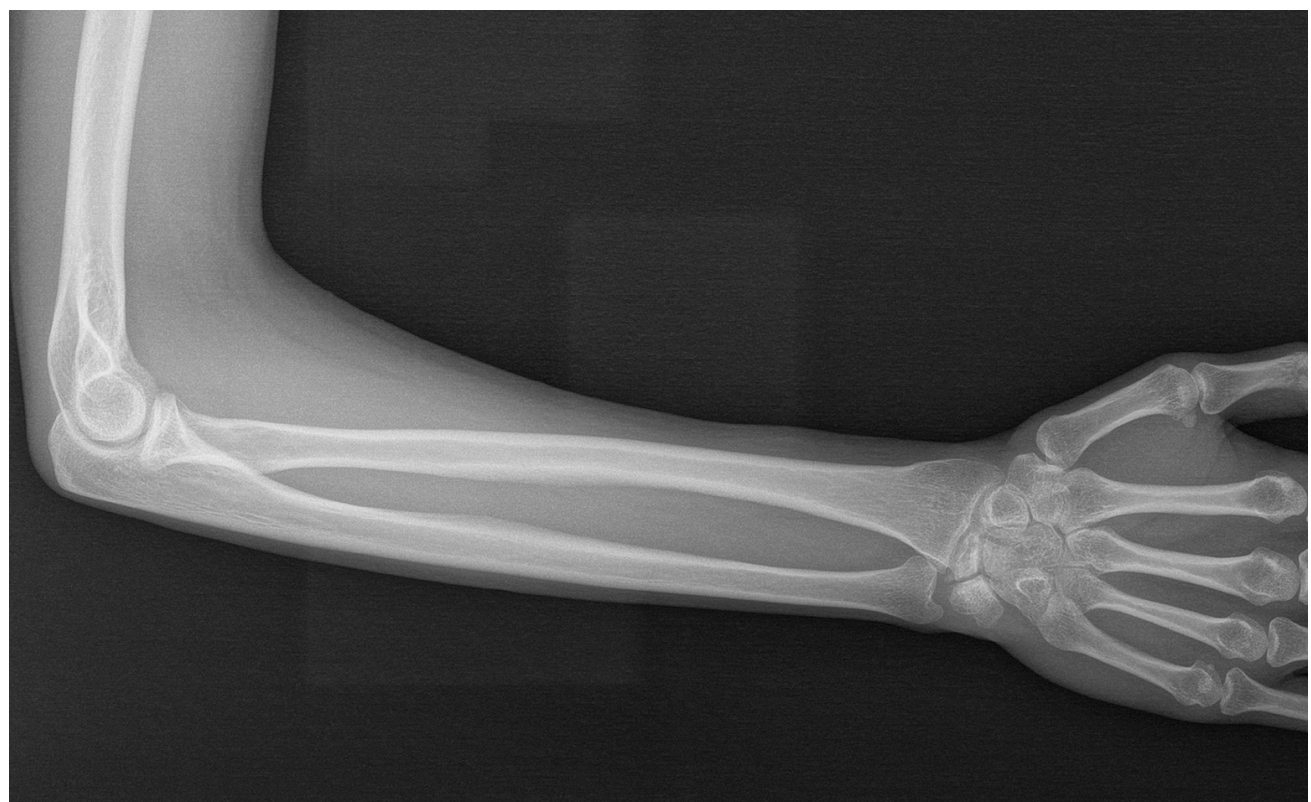

Şekil 3. Lunatumda avasküler nekroz (Kienböck hastalığı) olan hastada standart (gerçek) arka-ön el bilek röntgeni.

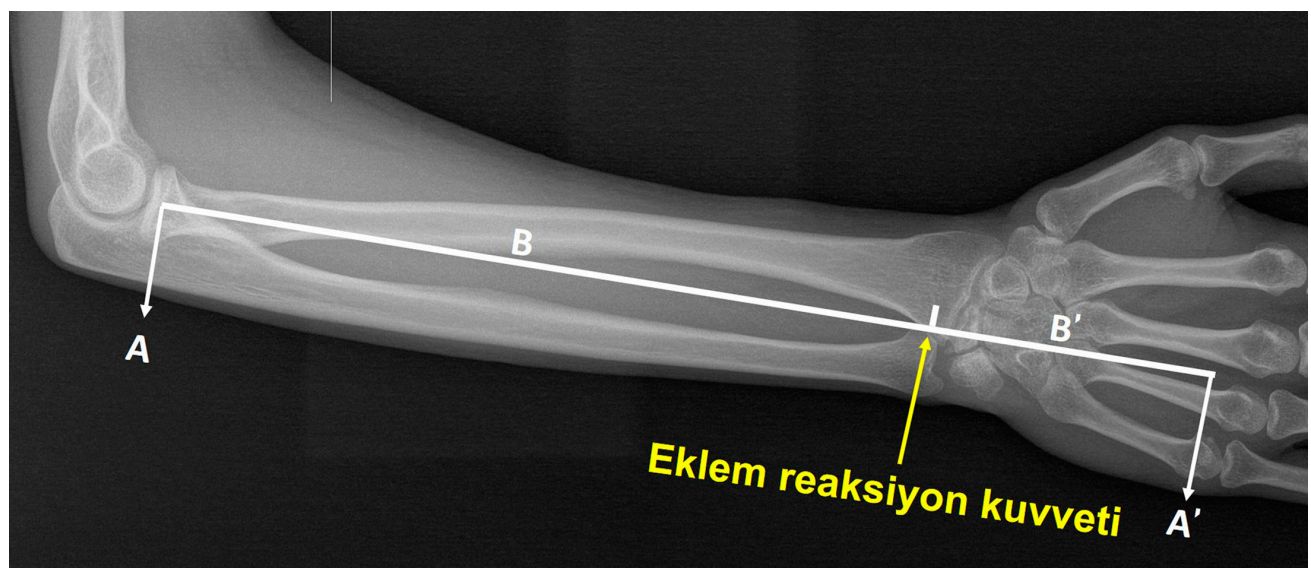

Şekil 4. Eklem reaksiyon kuvveti $=(A \times B)+\left(A^{\prime} \times B^{\prime}\right)$. 


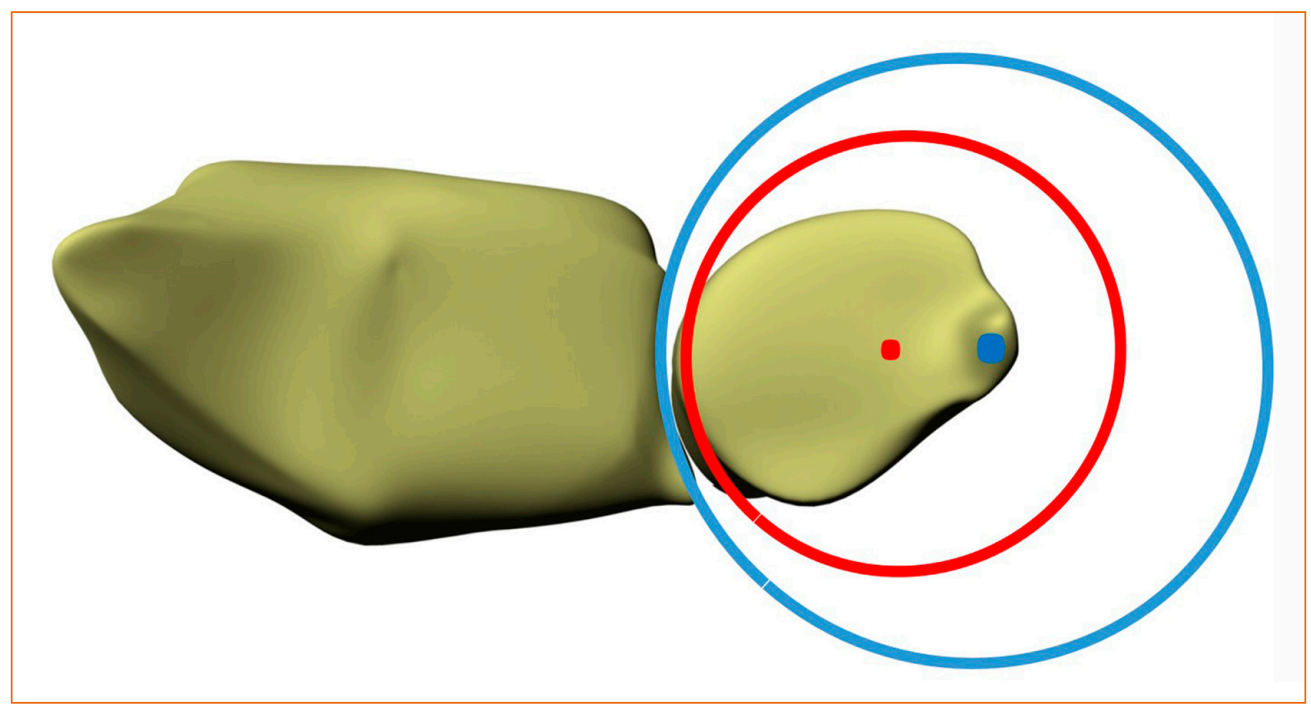

Şekil 5. Radius ve ulna distalinin transvers kesiti. Kırmızı nokta, ulna başının eklem yüzünün eğriliğinin çembersel merkezi olan ulnar foveayı, mavi nokta ise sigmoid çentiğin pro-supinasyon hareketi ile oluşturduğu çemberin merkezi olan ulnar stiloidi gösteriyor.

\section{STABILITE}

Distal radyoulnar eklem stabilitesi; (1) Kemiksel uyum, (2) Bağların bütünlüğü, (3) Kasların dinamik kompresyonu, (4) İnterosseöz membran, (5) Eklem kapsülü, (6) Propriyosepsiyon ile sağlanır. Kemiksel uyum ve bağların bütünlüğü stabilitede birincil öneme sahiptir.

\section{Kemiksel Uyum}

Distal radyoulnar eklem, radius distalinde ulnar taraftaki konkav sigmoid çentik ile ulna başındaki konveks eklem yüzeyinin oluşturduğu trokoid (pivot) tip sinovyal bir eklemdir. Bu eklem yüzeyleri birebir uyumlu değildir. Sigmoid çentiğin pro-supinasyon hareketi ile oluşturduğu çemberin merkezi ulnar stiloidde ve yarıçapı ortalama $15 \mathrm{~mm}$ iken, ulna başının eklem yüzünün eğriliğinin çembersel merkezi ulnar foveada ve yarıçapı ortalama $10 \mathrm{~mm}$ 'dir (Şekil 5). ${ }^{[6]}$ DRUE yüzlerindeki bu uyumsuzluk, ön kol rotasyon aksından $5 \mathrm{~mm}$ kadar sapmaya ve sigmoid çentiğin pronasyonda palmar ve proksimal yönde, supinasyonda ise dorsal ve distal yönde translasyonuna izin verir. ${ }^{[3]}$ El bileği nötral rotasyondayken DRUE teması \%60 iken, bu temas pronasyon ve supinasyonun ileri derecelerinde \%10'a kadar inmektedir. ${ }^{[6,7]} \mathrm{Bu}$ nedenle DRUE nötral rotasyonda kendi içinde stabildir ama pro-supinasyonun ilerleyen derecelerinde yumuşak doku stabilizatörlerine ihtiyacı artar. ${ }^{[8]}$ DRUE'deki uyumu bozacak çok az miktarda bir açılanma (angulasyon) (örneğin, distal radius kırı̆ğ sonrasında) DRUE instabilitesine neden olabilir.
Sigmoid çentik morfolojisi aksiyel planda 4 farklı tiptedir. Sigmoid çentik konkavitesi düz (\%42), pist eğimi şeklinde (ski slope) (\%14), "C" şeklinde (\%30) ve "S" şeklinde (\%14) olabilir (Şekil 6). ${ }^{[9]}$ Bu varyasyonların DRUE stabilitesinde etkisi olabilir, özellikle "S" şeklindeki sigmoid çentikte kemiksel stabilitenin daha iyi olduğu düşünülmektedir. Bununla birlikte her eklem özgün anatomisine göre kendi yapıları içinde stabilitesini sağlamaktadır.

\section{Bağların Bütünlüğü}

Radius ve ulna PRUE'de annular bağ, ön kol ortasında interosseöz membran, DRUE'de ise triangular fibrokartilaj kompleksi ile birbirine bağlanır. TFKK'yı oluşturan yapılar dorsal ve volar radyoulnar bağlar, eklem diski, ulnokarpal bağlar, menisküs homoloğu, ve ekstansör karpi ulnaris (EKU) kılıfıdır (Şekil 7). DRUE'nin statik stabilitesinden birinci derecede sorumlu bağlar, dorsal ve volar radyoulnar bağlardır. DRUE'nin ikincil statik stabilizatör bağları ise ulnokarpal (özellikle ulnolunat) bağlardır.

Dorsal radyoulnar (DRUL) bağ radiusun ulnar dorsal köşesinden, volar radyoulnar (VRUL) bağ radiusun ulnar volar köşesinden kaynaklanır. Her iki bağın yüzeysel ve derin lifleri vardır; yüzeysel lifler ulnar stiloide, derin lifler ise ulnar foveaya yerleşirler (Şekil 8). Derin liflerin dinamik yüklenmelerde stabilite açısından yüzeysel liflerden daha önemli olduğu Haugstvedt ve ark. tarafindan yapılan deneysel çalışmada gösterilmiştir. ${ }^{[10]}$ 

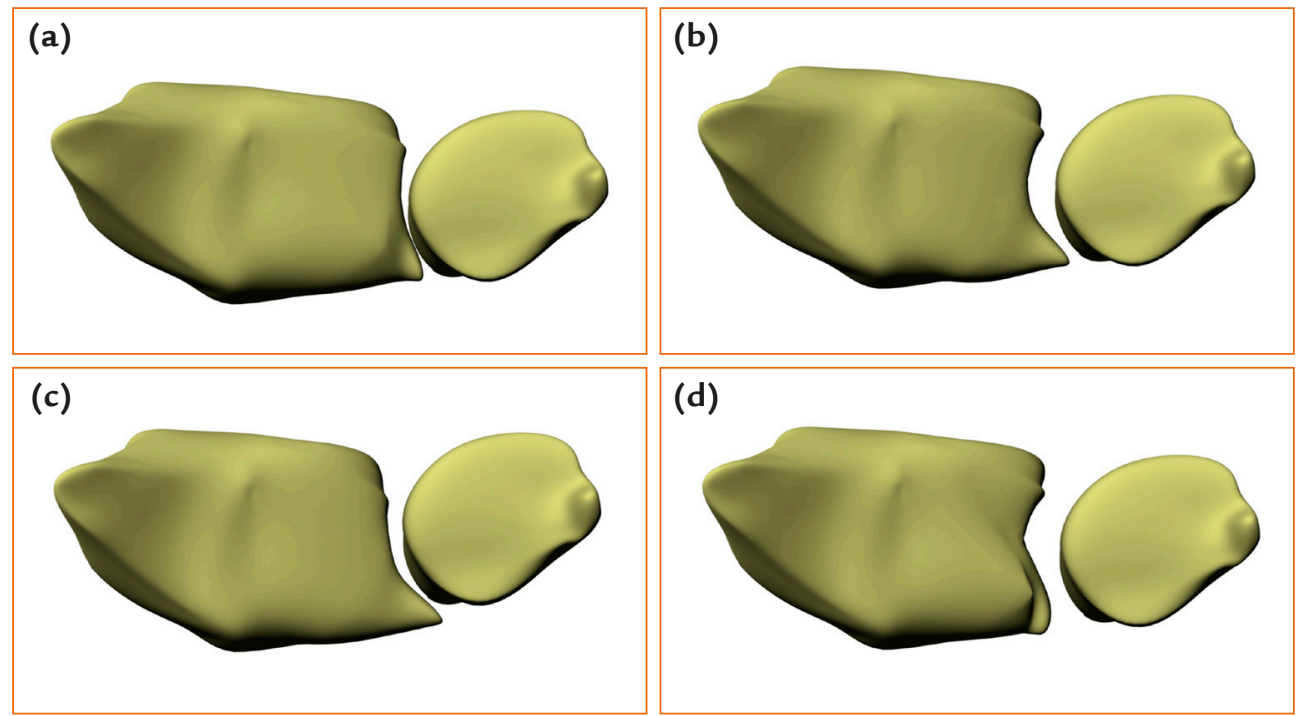

Şekil 6. a-d. Sigmoid çentik morfolojileri. Düz (\%42) (a), “C” şeklinde (\%30) (b), Pist eğimi (ski slope) (\%14) (c), "S" şeklinde (\%14) (d).

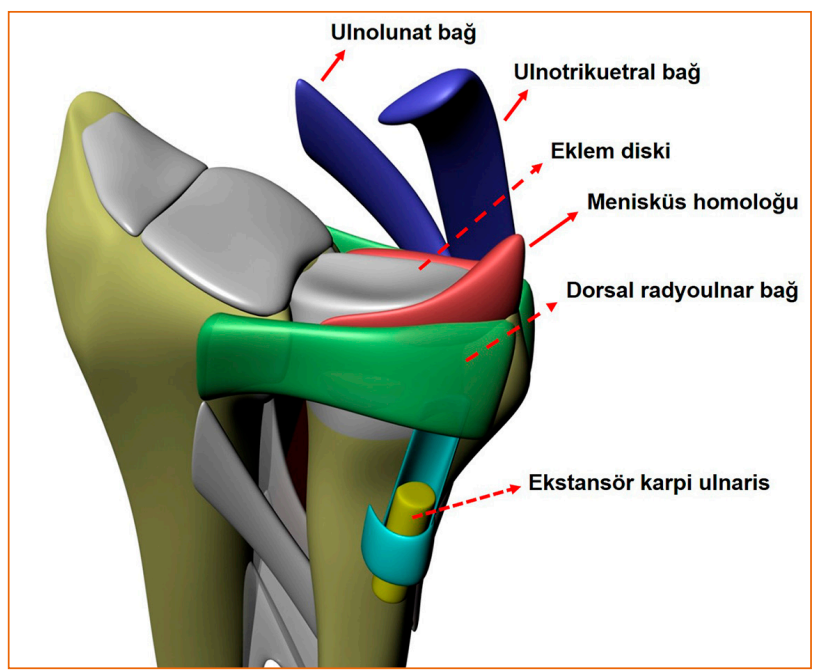

Şekil 7. Triangular fibrokartilaj kompleksi (volar radyoulnar bağ gösterilmemiştir).

Pronasyon ve supinasyonda hangi radyoulnar bağın birincil stabilizatör olduğu ise uzun yıllar boyunca tartışılmıştır. ${ }^{[11]}$ Son yıllardaki çalışmalar, pronasyonda distal radyoulnar ligamentin (DRUL) yüzeysel lifleri ile volar radyoulnar ligamentin (VRUL) derin lifleri, supinasyonda ise VRUL'nin yüzeysel lifleri ile DRUL'nin derin lifleri gergin olmaktadır. ${ }^{[2,12,13]}$ Bununla birlikte, radyoulnar bağların DRUE stabilitesine etkisi sadece liflerdeki gerginlik üzerinden olmamakta, gergin olmayan liflerin de DRUE'ye kompresyon uygulayarak stabiliteyi artırdığı düşünülmektedir. ${ }^{[13]}$ DRUL ve VRUL lifleri yapışma

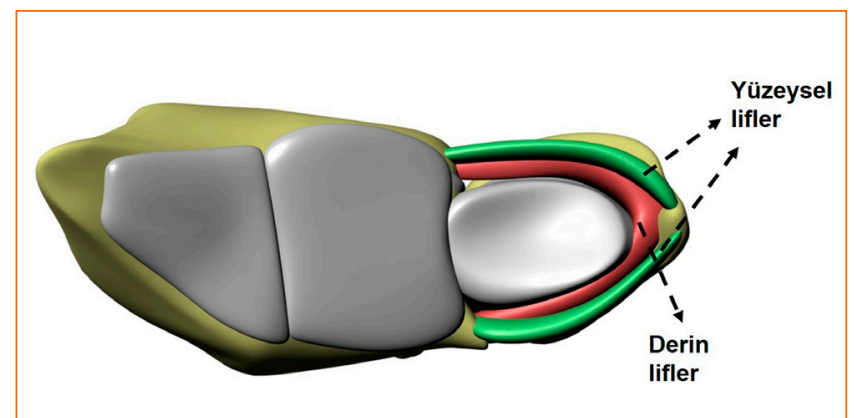

Şekil 8. Radyoulnar bağların yüzeysel ve derin lifleri; yüzeysel lifler ulnar stiloide, derin lifler ise ulnar foveaya yerleşir.

yerlerine doğru kendi içinde de spiral bir yapıya dönüşürler ve pro-supinasyon hareketleri esnasında liflerin bir kısmı gerginlik sağlayarak, bir kısmı da DRUE kompresyonuna etki ederek stabilitede rol oynarlar. ${ }^{[13]}$ Radyoulnar bağlar bu şekilde, asma germe sistemi (tensegrity, tension [germe] + integrity [bütünsellik]) olarak ifade edilen mimari yapıyla DRUE stabilitesini sağlamaktadır.

Ulnokarpal bağlar ulnolunat ve ulnotrikuetral bağlardır, ulna ile karpal kemikleri bir arada tutarak pro-supinasyon esnasında elin ön kol ile aynı düzlemde rotasyonunu sağlarlar (Şekil 7). Çalışmalarda, ulnolunat bağın DRUE stabilitesinde önemli olduğu, ulnotrikuetral bağın ise eklem diski ve menisküs homoloğu ile birlikte ekleme olan aksiyel yüklenmelerde şok absorpsiyonu görevi yaptığı bildirilmiştir. ${ }^{[14]}$ 


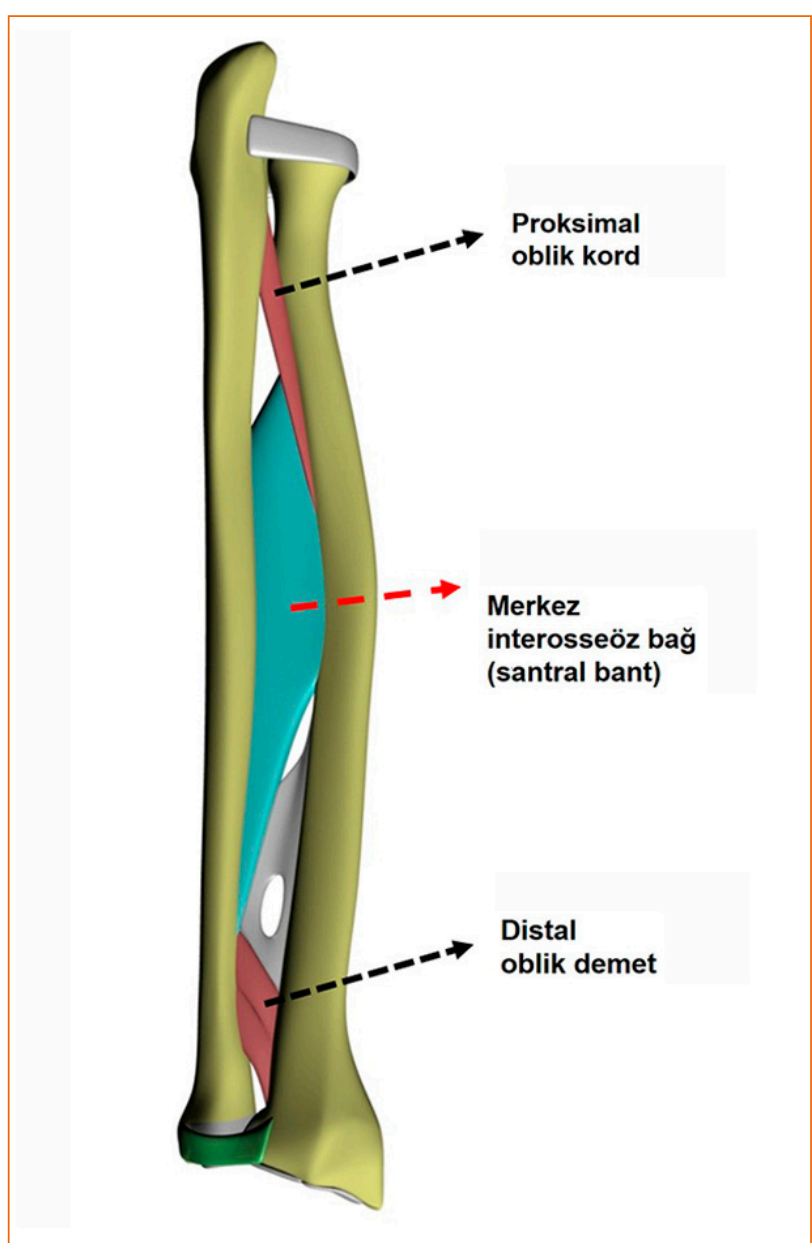

Şekil 9. İnterosseöz membranın bileşenleri.

\section{Kasların Dinamik Kompresyonu}

Pronasyon, pronator teres ve pronator kuadratus, supinasyon ise biseps brachii ve supinator kaslarının kasılması sonucu gerçekleşir. Diğer kasların da DRUE dinamik stabilitesine etkisi olmakla birlikte direkt etki eden kas pronator kuadratustur (PK). PK kasının özellikle derin başı pro-supinasyon hareketleri esnasında DRUE'ye kompresyon uygulayarak dinamik stabilizatör olarak görev yapar. ${ }^{[15,16]}$ Derin başın, DRUE kapsülünün volar ve ulnar kısmı ile yakın ilişkide olduğu histolojik çalışmalarda gösterilmiş ve pro-supinasyon hareketlerinde kapsülü gererek eklem arasına kaçmasına engel olduğu düşünülmüştür. ${ }^{[17]}$

Ekstansör karpi ulnaris tendonu, pro-supinasyon hareketi boyunca radiusla birlikte hareket eden diğer tendonlardan farklı olarak, kılıfi ile birlikte ulna başının üzerinde kalır (Şekil 7). Bu şekilde ulna başının deplasmanına engel olarak DRUE'nin stabilizasyonuna katkıda bulunur. ${ }^{[18]}$

\section{İnterosseöz Membran}

İnterosseöz membran (IOM) el bileğindeki aksiyel yüklenmelerin proksimale, radiustan ulnaya ve dirsek eklemine aktarılmasında rol alır (Şekil 9). ${ }^{[11]}$ DRUE stabilitesinde rolü olduğu düşünülen distal oblik demet, iOM'nin distaldeki kısmıdır. ${ }^{[19,20]}$ DRUL'nin yaralandığı durumlarda veya ulnar kısaltma ameliyatlarından sonra DRUE stabilizasyonu için distal oblik demet önem kazanmaktadır. ${ }^{[21,22]}$

\section{Eklem Kapsülü}

Kapsülün el bileği nötral rotasyondayken, DRUE önarka stabilitesine katkısı olabileceği düşünülmüştür. Kadavralarda yapılan bir çalışmada volar kapsül kesilmesinin tam supinasyon pozisyonunda dorsal instabiliteye, dorsal kapsülün kesilmesinin ise tam pronasyon pozisyonunda volar instabiliteye neden olduğu gösterilmiştir. ${ }^{[11,23]}$

\section{Propriyosepsiyon}

Propriyosepsiyon, bir eklemin bağ ve kapsüllerinde bulunan mekanoreseptörlerden gelen afferent sinyallere göre kasların ilgili eklemin dinamik stabilitesini düzenlemesidir. Radyoulnar bağlarda çok sayıda mekanoreseptör olduğu gösterilmiştir ve bu bağların DRUE stabilitesinde önemli bir propriyoseptif fonksiyonu da olduğu düşünülmektedir. ${ }^{[24]}$

\section{SONUÇ}

Distal radyoulnar eklemin hareketli ve stabil olması, kemik ve bağlar gibi statik bileşenlerin bütünlügüne ve uyumuna ek olarak nöromusküler yapıların dinamik etkinliğine bağlıdır. Dolayısıyla bu mükemmel uyumun bozulması; stabilitenin artıp hareketin azalmasına (DRUE osteoartriti), hareketin artıp stabilitenin azalmasına (TFKK hasarı sonrası DRUE instabilitesi) ya da hem hareketin hem de stabilitenin azalmasına (radius distal kırığı sonrası kötü kaynama) neden olmaktadır. Bu gibi klinik durumların ortak sonucu da ağrı, kuwetsizlik ve hareket kısıt|lığı ile kendini gösteren üst ekstremitede fonksiyonel yetmezliktir. DRUE, muhtemelen, hemen yakın komşuluğunda olan ve daha büyük ve önemli gibi gözüken radyokarpal eklem nedeniyle gözden kaçabilmekte ya da daha az önemsenebilmektedir. Ne var ki, DRUE ön kol ekleminin bir kondili olarak düşünüldügünde, anatomik açıdan oldukça büyük bir eklemdir. Radyokarpal artrodezle ve hatta midkarpal eklemi içeren el bileği artrodeziyle karşılaştıııldığında, ön kol ekleminin artrodezi (tek-kemik ön kol) çok daha ciddi fonksiyon kaybı ile sonuçlanmaktadır. Ulna başı yük taşıma esnasında radiusa destek olmaktadır. Bunlar ve benzeri birçok nedenlerden dolayı DRUE bileşenleri daima korunmaya ve anatomik restore edilmeye çalışılmalıdır. 


\section{Teşekkür}

Şekillerin hazırlanmasında verdiği emekler için değerli hocamız Prof. Dr. Cengiz Yılmaz'a teşekkür ederiz.

\section{KAYNAKLAR}

1. Linscheid RL. Biomechanics of the distal radioulnar joint. Clin Orthop Relat Res 1992;(275):46-55. Crossref

2. Hagert CG. Distal radius fracture and the distal radioulnar joint -anatomical considerations. Handchir Mikrochir Plast Chir 1994;26(1):22-6. https://pubmed.ncbi.nlm.nih. gov/8150382/

3. Kleinman WB. Stability of the distal radioulna joint: biomechanics, pathophysiology, physical diagnosis, and restoration of function. What we have learned in 25 years. J Hand Surg Am 2007;32(7):1086-106. Crossref

4. Palmer AK, Werner FW. Biomechanics of the distal radioulnar joint. Clin Orthop Relat Res 1984;(187):26-35. Crossref

5. Schuind F, An KN, Berglund L, Rey R, Cooney WP, Linscheid RL, Chao EYS. The distal radioulnar ligaments: a biomechanical study. J Hand Surg 1991;16A:1106-14. Crossref

6. Ekenstam FAF, Hagert CG. Anatomical studies on the geometry and stability of the distal radio ulnar joint. Scand J Plast Reconstr Surg 1985;19(1):17-25. Crossref

7. Hagert CG. The distal radioulnar joint. Hand Clin 1987;3(1):41-50. Crossref

8. Kakar S, Carlsen BT, Moran SL, Berger RA. The management of chronic distal radioulnar instability. Hand Clin 2010;26(4):517-28. Crossref

9. Tolat AR, StanleyJK, Trail IA. A cadaveric study of the anatomy and stability of the distal radioulnar joint in the coronal and transverse planes. J Hand Surg Br 1996;21(5):587-94. Crossref

10. Haugstvedt JR, Berger RA, Nakamura T, Neale P, Berglund L, An KN. Relative contributions of the ulnar attachments of the triangular fibrocartilage complex to the dynamic stability of the distal radioulnar joint. J Hand Surg Am 2006;31(3):44551. Crossref

11. Haugstvedt JR, Langer MF, Berger RA. Distal radioulnar joint: functional anatomy, including pathomechanics. J Hand Surg Eur Vol 2017;42(4):338-45. Crossref

12. $\mathrm{Xu} \mathrm{J}$, Tang JB. In vivo changes in lengths of the ligaments stabilizing the distal radioulnar joint. J Hand Surg Am 2009;34(1):40-5. Crossref
13. Hagert E, Hagert CG. Understanding stability of the distal radioulnar joint through an understanding of its anatomy. Hand Clin 2010;26(4):459-66. Crossref

14. Semisch M, Hagert E, Garcia-Elias M, Lluch A, Rein S. Histological assessment of the triangular fibrocartilage complex. J Hand Surg Eur Vol 2016;41(5):527-33. Crossref

15. Gordon KD, Pardo RD, Johnson JA, King GJ, Miller TA. Electromyographic activity and strength during maximum isometric pronation and supination efforts in healthy adults. J Orthop Res 2004;22(1):208-13. Crossref

16. Sakamoto K, Nasu H, Nimura A, Hamada J, Akita K. An anatomic study of the structure and innervation of the pronator quadratus muscle. Anat Sci Int 2015;90(2):82-8. Crossref

17. Stuart PR. Pronator quadratus revisited. J Hand Surg $\mathrm{Br}$ 1996;21:714-22. Crossref

18. Garcia-Elias M. Soft-tissue anatomy and relationships about the distal ulna. Hand Clin 1998;14(2):165-76. Crossref

19. Noda K, Goto A, Murase T, Sugamoto K, Yoshikawa H, Moritomo $\mathrm{H}$. Interosseous membrane of the forearm: an anatomical study of ligament attachment locations. J Hand Surg Am 2009;34(3):415-22. Crossref

20. Kitamura $\mathrm{T}$, Moritomo $\mathrm{H}$, Arimitsu S, Berglund LJ, Zhao KD, An KN, Rizzo M. The biomechanical effect of the distal interosseous membrane on the distal radioulnar joint stability: a preliminary anatomic study. J Hand Surg Am 2011;36(10):1626-30. Crossref

21. Watanabe H, Berger RA, Berglund LJ, Zobitz ME, An KN. Contribution of the interosseous membrane to distal radioulnar joint constraint. J Hand Surg Am 2005;30(6):116471. Crossref

22. Moritomo $\mathrm{H}$. The distal oblique bundle of the distal interosseous membrane of the forearm. J Wrist Surg 2013;2(1):93-4. Crossref

23. Watanabe H, Berger RA, An KN, Berglund LJ, Zobitz ME. Stability of the distal radioulnar joint contributed by the joint capsule. J Hand Surg Am 2004;29(6):1114-20. Crossref

24. Rein S, Semisch M, Garcia-Elias M, Lluch A, Zwipp H, Hagert E. Immunohistochemical Mapping of Sensory Nerve Endings in the Human Triangular Fibrocartilage Complex. Clin Orthop Relat Res 2015;473(10):3245-53. Crossref 